\title{
BizALOM A FELSŐOKTATÁSBAN
}

\author{
FÁBRI GYÖRGY
}

ELTE

\begin{abstract}
A bizalom nem pusztán általános szervezeti-közösségi szempontból érinti a felsőoktatást. A hallgatók továbbtanulási motivációiban, a fenntartók és az állami irányítás szervezeti megoldásaiban és az egyéni, illetve finanszírozási döntésekben jelentős szerepe van a bizalomnak, így azok konkrétan befolyásolják az egyetemi múködést, irányítási és pénzügyi szempontból egyaránt. A tanulmány empirikus kutatások alapján elemzi, hogy a magyar felsőoktatást jelentős közbizalom övezi, a nemzetközi kitekintés pedig jelzi, hogy a társadalom politikai polarizációja kihathat az egyetemek megítélésére is, amint ez az USA-ban történt. A továbbtanulási adatok elemzése a hallgatói bizalom stabilitását bizonyítja, miközben a felsőoktatás-politika orientáló prioritásainak elfogadása csak részben jellemző a jelentkezőkre. A bizalom elvének érvényesülése a felsőoktatási irányításban hatékonyabb megoldásokhoz vezet, mint a bürokratikus és a bizalmatlanságon alapuló túlszabályozás, amit egy alternatív modell bemutatásával is szemléletet a tanulmány.
\end{abstract}

Kulcsszavakः bizalom, reputáció, felsőoktatás, Magyarország

Trust does not only affect higher education from a general organizational-community perspective. Students' motivation for higher education, organizational solutions promoted by maintainers and policy-makers and mechanisms have a direct impact on university performance, even at a 'material' level. Based on empirical research, this study analyzes that Hungarian higher education has high level of public confidence, but that the international outlook indicates that the political polarization of society may also affect the perception of universities, as happened in the USA. The analysis of higher education admission and application data demonstrates the stability of student demand, while the acceptance of higher education policy priorities is only partially affects applicants. The application of the principle of trust in higher education management leads to more effective solutions than bureaucratic and mistrust-based overregulation, which is also illustrated by an alternative model.

Keywords: trust, confidence, reputation, higher education, Hungary

Levelező szerző: Fábri György, ELTE, 1064 Budapest, Izabella u. 46. E-mail: gyorgy.fabri@ppk.elte.hu 
B ízik-e a társadalom a felsőoktatásban? Működik-e a bizalmi elv a felsőoktatás és a felsőoktatás-politika, vagyis a fenntartói-ágazati irányítási vezetés és az intézmények között? A tanulmány címének kettős értelme ennek a külső és belső bizalomnak a helyzetét és jelentőségét igyekszik empirikus kutatások, továbbtanulási adatelemzések, illetve egy felsőoktatás-politikai esettanulmány révén feltárni. „Külső” bizalomnak a felsőoktatást övező társadalmi megítélést nevezem, amely a felsőoktatásról való ismeretekben és a felsőoktatási teljesítmény értékelésében nyilvánul meg. Ennek mérésére alkalmasnak bizonyult a felsőoktatás percepcióját feltáró empirikus kutatásunk. A „belső” bizalom az intézményrendszeri szereplők egymáshoz való viszonyát jellemzi, ami az igazgatási-irányítási és döntéshozatali kompetenciákban testesül meg.

A tanulmány először a társadalmi percepció empirikus adatai alapján értelmezi a magyar egyetemet övező közbizalmat, majd az USA példáját felhasználva a közvélekedés átpolitizálódásának jelenségét mutatja be. A magyar továbbtanulók intézményválasztása ezzel szemben nem ideologikus és meglehetősen stabil, ezt igazolják a tanulmány következő részének adatai. Viszont a belső bizalmi helyzet romlik a magyar felsőoktatásban: a kormányzati felsőoktatás-irányítás bizalmatlanságát kifejező megoldásokat elemezve juthatunk erre a következtetésre.

\section{A felsőoktatás társadalmi percepciója}

A felsőoktatás iránti társadalmi bizalom központi helyen szerepelt abban az empirikus felmérésben, amely egy 1500 fős országos reprezentatív lakossági, 1500 fős fiatal felnőtt, 250 fös $\mathrm{PhD}$-fokozatot szerzett mintán, valamint középiskolások online megkérdezésével készült 2013-ban. A „Kvalitatív és kvantitatív felmérés, országos és regionális reprezentatív attitűd vizsgálatok, elemzések kutatás-fejlesztési szolgáltatás" ${ }^{1}$ kutatásban a továbbtanulási motivációkat, valamint a felsőoktatással kapcsolatos általános attitüdöt mértük fel ezeken a mintákon.

Az eredmények alapján az általános bizalom igen magas Magyarországon a tudásintézmények, vagyis az egyetemek (a kérdőívben ezzel a megjelöléssel dolgoztunk a felsőoktatást illetően) és az MTA iránt. Az is figyelemre méltó, hogy sem az életkor, sem az iskolai végezettség nem befolyásolja érdemben a bizalom mértékét: az egyetemek a teljes mintán és a diplomások között is az első helyen vannak, a 18-29 év közöttieknél valamivel az MTA mögé szorulnak a listán, de így is messze kiemelkednek a többi társadalmi intézmény közül.

1. táblázat: Társadalmi intézmények bizalmi indexe (1: egyáltalán nem bízik benne 4 teljesen megbízik benne; 2013, országos minta $\mathrm{n}=1500$ )

\begin{tabular}{lccc}
\hline & Összes & $18-29$ év & Diplomás \\
\hline Egyetemek & 3,20 & 3,10 & 3,21 \\
MTA & 3,09 & 3,19 & 3,20 \\
Alkotmánybíróság & 2,74 & 2,61 & 2,8 \\
Köztársasági elnök & 2,67 & 2,36 & 2,68 \\
\hline
\end{tabular}

TÁMOP-7.2.1-11/K-2012-0005, Oktatási Hivatal. 
1. táblázat: (folyt.)

\begin{tabular}{lccc}
\hline & Összes & $18-29$ év & Diplomás \\
\hline Helyi önkormányzat & 2,71 & 2,44 & 2,70 \\
Bíróságok & 2,65 & 2,61 & 2,66 \\
Rendőrség & 2,63 & 2,54 & 2,65 \\
Hadsereg & 2,60 & 2,57 & 2,58 \\
Kereskedelmi bankok & 2,03 & 2,10 & 2,04 \\
Napilapok & 2,22 & 2,13 & 2,15 \\
Egyházak & 2,51 & 2,28 & 2,44 \\
Parlament & 2,21 & 2,05 & 2,22 \\
Biztosítók & 2,04 & 2,10 & 2,03 \\
Szakszervezet & 2,06 & 1,99 & 2,10 \\
Kormány & 2,18 & 2,00 & 2,19 \\
Politikai pártok & 1,90 & 1,76 & 1,76 \\
\hline
\end{tabular}

Ez a hazai viszonyítású bizalmi pozíció nemzetközi összevetésben is megvan. A válaszadók $12 \%$-a szerint a magyarországi egyetemek a legjobbak között vannak a világon, és további $41 \%$-uk szerint jobbak az átlagnál. 44\%-uk szerint a magyar egyetemek átlagos színvonalúak. A megkérdezetteknek csupán 3\%-a állítja, hogy rosszabbak az átlagnál. A viszonyítás fontosságát mutatja az is, hogy a semleges válaszok aránya nagyon alacsony, vagyis kifejezetten mozgósító erejü a téma - többségében pozitív elköteleződést mutatva a magyar felsőoktatás értékei mellett.

Nem meglepő ezek után, hogy majd négyszer annyian gondolják a magyar felsőoktatást az ország hírneve számára értékhordozó tényezőnek. Az összes megkérdezett fele egyértelműen pozitívan válaszolt erre a kérdésre, míg a teljes minta alig 13\%-a látja erre alkalmatlannak.

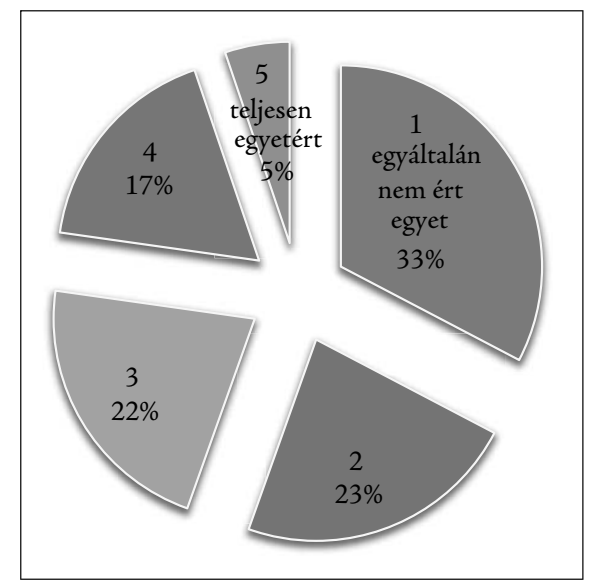

1. ábra: „A magyarországi egyetemek minősége, az ott szerzett tudás gyengébb, mint a nyugat-európai egyetemeké." (2013, országos lakossági minta, $N$ = 1423) 
Ez a pozitív kép a korcsoportok bontásában nem mutat különösebb eltérést, csupán a legidősebbek és a legfiatalabbak között látszik tíz százalékos eltérés azok között, akik kifejezetten jónak tartják a hazai egyetemeket a nyugat-európaiakkal szemben, és úgy tűnik, ebben az idősebbeknek van szilárdabb véleményük, míg a fiatalabb, 18-29 év közötti korosztály harmada semlegesen viszonyult a kérdéshez. Az iskolai végzettséget tekintve már szignifikáns eltérések mutatkoznak, és egyértelmű tendencia figyelhető meg. Minél magasabb az iskolai végzettség, annál inkább úgy gondolja a válaszadó, hogy a magyarországi egyetemek minősége jobb, mint a nyugat-európai egyetemeké. Míg a felsőfokú végzettségủek között ez az arány 65,7\%, addig az alapfokú végzettségúek között mindössze 45,3\%, tehát 20\%-os eltérés mutatkozik a két szélső iskolai csoport között. Úgy tűnik, hogy akiknek volt alkalmuk megtapasztalni a hazai felsőoktatás minőségét, egyértelműen elégedettek vele, hiszen kétharmaduk így nyilatkozott, és mindössze 17\% véli úgy, hogy gyengébben teljesítenek a hazai egyetemek.

A diplomások hasznosabb tagjai a társadalomnak, mint az alacsonyabb képzettségüek

A magyarországi egyetemek minősége, az ott szerzett tudás gyengébb, mint a nyugat-európai egyetemeké

$\mathrm{A} z$ állam túl sokat költ a felsőoktatásra

Az egyetemisták túl sokat tüntetnek, vitatkoznak, inkább tanulniuk kellene

Ma diplomával könnyebb elhelyezkedni, mint diploma nélkül

A diáktüntetések természetes velejárói az egyetemi életnek

Akkor lesz jobb a gazdaság, ha előbb többet költünk felsőoktatásra

Legyen több diplomás, mert ők viszik előre az országot

A diploma mögött gyakran nincs valós tudás, sokan csak papírt szereznek a felsőoktatásban

A diplomások lenézik az alacsonyabb képzettségüeket

Rossz anyagi helyzetü családból nem lehet bejutni egyetemre, föiskolára

Magyarország hírnevét a felsőoktatás javítja a világban

Csak olyan ember lehessen vezető pozícióban, akinek van diplomája

Előbb legyen jobb a gazdaság, utána költsünk többet a felsőoktatásra

Inkább szakmát tanuljanak a fiatalok, ne egyetemre akarjanak járni

Túl sok a diplomás, mert sokan nem akarnak kétkezi munkát végezni

Egy diplomásnak jelentősen többet kellene keresnie, mint egy alacsonyabb képzettséggel rendelkezőnek

Aki diplomát szerzett állami finanszírozással, annak legyen kötelezö ugyanannyi vagy hosszabb ideig Magyarországon...

A diplomások között magas a munkanélküliek aránya

Ma sok diplomás olyan munkát végez, amihez nem is lenne szükség diplomára

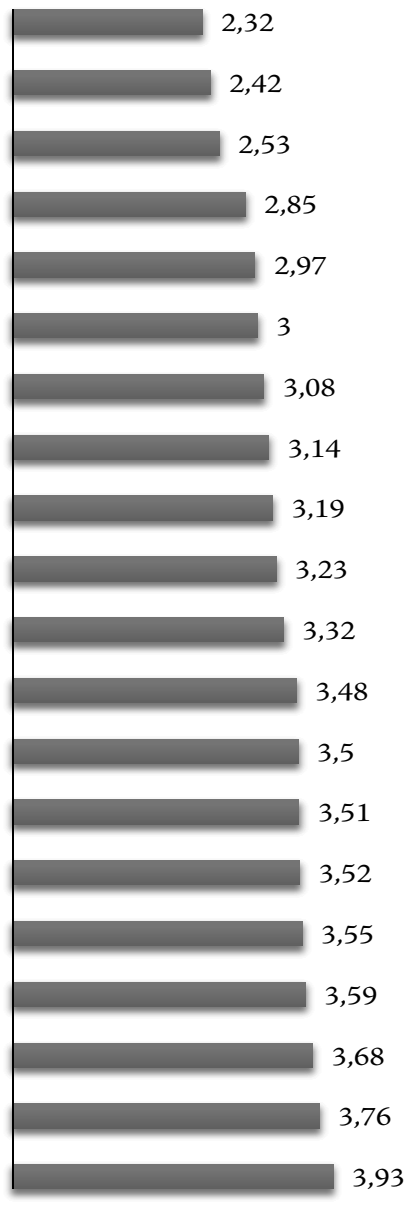

2. ábra: Mennyire ért azzal egyet, hogy ... (5: teljesen egyetért - 1: egyáltalán nem ért vele egyet; $N=1246$, lakossági) 
Tehát a magyar felsőoktatás általános bizalmi környezete pozitív visszajelzést ad az intézményrendszer egészének. Ha szegmentáljuk ezt a viszonyulást a felsőoktatással kapcsolatos közbeszédtoposzok szerint, tagoltabban is értelmezni tudjuk ezt az általános attitűdöt. (Az külön elemzést igényel, hogy mindebben miképpen választható szét a reputáció és a bizalom, illetve, hogy ezekben a teljesítmény, a minőség milyen fogalmai jelennek meg, különös tekintettel a felsőoktatás és diploma funkcióit illető, tagolt elvárások különbözőségeire.)

A képzéseket egyfelől nemzetközi szinten is versenyképesnek tartják, azonban a diplomák mögötti valós tudást gyakran keveslik - ez az ellentmondásos vélekedés rajzolódik ki a válaszokból. A felmérés további részében, a kiemelt célcsoportok között a diplomások és a felsőoktatásban tanulók elégedettek a megszerzett tudással, az oktatók tevékenységével, s ugyanilyen visszajelzést adnak doktoráltak is. A lakossági, illetve a felsőoktatástól távolabb álló fiatal felnőttek körében sem fogalmazódott meg negatív vélemény a felsőoktatás minőségével kapcsolatban.

A társadalmi percepció ambivalenciája ugyanakkor itt is tetten érhető. Hiszen miközben nehéznek, vagyis érdemi munkát, tanulást kívánónak tételezik a diplomát, a frázisok szintjén mégis sokan, a felnőttek több mint 40\%-a gondolja úgy, hogy gyakran nincs tudás a diploma mögött.

A felsőoktatásnak - mint a gazdasági gyarapodás egyik legfontosabb tényezőjének - a magyar közbeszédben tapasztalt megítélése komoly változást mutat. A korábbi időszakokban a tudástőkébe való befektetés kifejezetten a gazdasági fejlődés motorjaként fogalmazódott meg a közvéleményben, szinte közhelyes volt az oktatási ráfordítások perspektivikusságát hangsúlyozni. A lakossági minta válaszai ebben elbizonytalanodást tükröznek, hiszen kiugróan magas az e tárgyú kérdésekre adott válaszokban a középérték aránya, mindhárom ilyen jellegü kérdésnél megfigyelhető, hogy a válaszadók több mint egyharmada nem tud valójában állást foglalni. Azt csak a válaszolók kicsit kevesebb mint egynegyede vitatja, hogy több diplomással előbbre tartana az ország, miközben több mint egyharmad egyetért ezzel, viszont a felsőoktatásra való ráfordítások gazdasági hasznosulásával szemben inkább negatív a többség álláspontja. Ezt ugyanis csak a gazdasági helyzet javulása után tartják kívánatosnak.

A kérdést az életkori változók mentén vizsgálva azt látjuk, hogy a fiatalabb korosztály (18-29 évesek) kevésbé érzi úgy, hogy a diplomások magas száma a kétkezi munka alacsony népszerüsége miatt alakult volna ki, a válaszadók ezen csoportjának mindöszsze 42\%-a ért egyet az állítással, míg a 30-45 évesek között 56,1\% az arány, és a 46-65 évesek között 57,5\%. A szakmával kapcsolatban nagyon hasonló eredmények születtek, 45,5\% és 50\% között mozog azok aránya, akik szerint inkább szakmát kéne tanulniuk a fiataloknak, és a két szélső korcsoport között a legnagyobb a különbség; az idősebbek inkább egyetértenek ezzel az állítással.

$\mathrm{A} z$ értékítélet konfúzusságát jelzi, hogy a lakosság többsége úgy gondolja, azért sok a diplomás, mert nem akarnak kétkezi munkát végezni, ugyanakkor azzal is egyetért a megkérdezettek 37\%-a, hogy a több diplomás előbbre vinné az országot. A társadalom honorálja, ha valaki diplomát kap: kifejezetten elvárja a többség, hogy a vezető pozíciókat diplomások töltsék be, és a fizetésben is lényeges előnyt követelne meg a diplomások számára. Azonban ez az elismerés egyáltalán nem kritika nélküli. Kevesen gondolják úgy, hogy az egyetemet végzettek hasznosabb tagjai lennének a társadalomnak, mint az 
alacsonyabb képzettségűek, a megkérdezetteknek mindössze 19\%-a értett egyet az erre vonatkozó állítással.

A felsőfokú végzettséget gazdaságilag az egyén számára profitábilisnak tartják. A gazdaság előnye nem jelenik meg, de az ország számára hasznosnak tartják a diplomásokat. A gazdasági fejlődést nem kötik a felsőoktatásra fordítandó többletfinanszírozáshoz. Ezek a vélemények alulbecsülik a diploma hasznát a munkaerőpiacon mind az elhelyezkedés, mind a kereset tekintetében. Arra vonatkozóan, hogy a gazdaságnak és az országnak milyen többletet jelent a diplomások tevékenysége, csak körvonalazatlan és többségi támogatást nem bíró elképzelésekkel rendelkeznek a kérdezettek.

A felsőoktatás iránti bizalom az egyén számára a saját karrierútban betöltött szerepével is kifejeződik. A sajátosan érintettek, az életpálya elején tartó fiatal felnőttek véleményét a felsőfokú végzettség közvetlen munkaerőpiaci értékéről meghatározza, hogy köztük viszonylag alacsony a felsőfokú végzettséggel rendelkezők aránya. Így a többség a végzettséget, szaktudást kiemelten fontosnak tartja, de magáról a diplomáról, tehát a felsőoktatáshoz leginkább közvetlenül kapcsolódó tényezőről sokkal kevesebben nyilatkoztak így.

Ezzel szemben a középiskolások, akik tervezik a továbbtanulásukat, döntő többségükben a diplomát nagyon szükségesnek, elengedhetetlennek tartották az érvényesülés szempontjából (79\%). Csupán 18\% szerint nem szükséges, 3\% szerint egyáltalán nem szükséges. Az egyetemi, illetve föiskolai diploma értékét tekintve szinte egyöntetű módon a pozitív megítélést tükrözik a középiskolai tanulók válaszai: $10 \%$ szerint sokkal többet keres az a személy, aki diplomával rendelkezik, 53\% gondolja úgy, hogy biztosan többet keres egy diplomás, 32\% szerint nagyjából mindegy, hogy felsőfokú végzettséggel

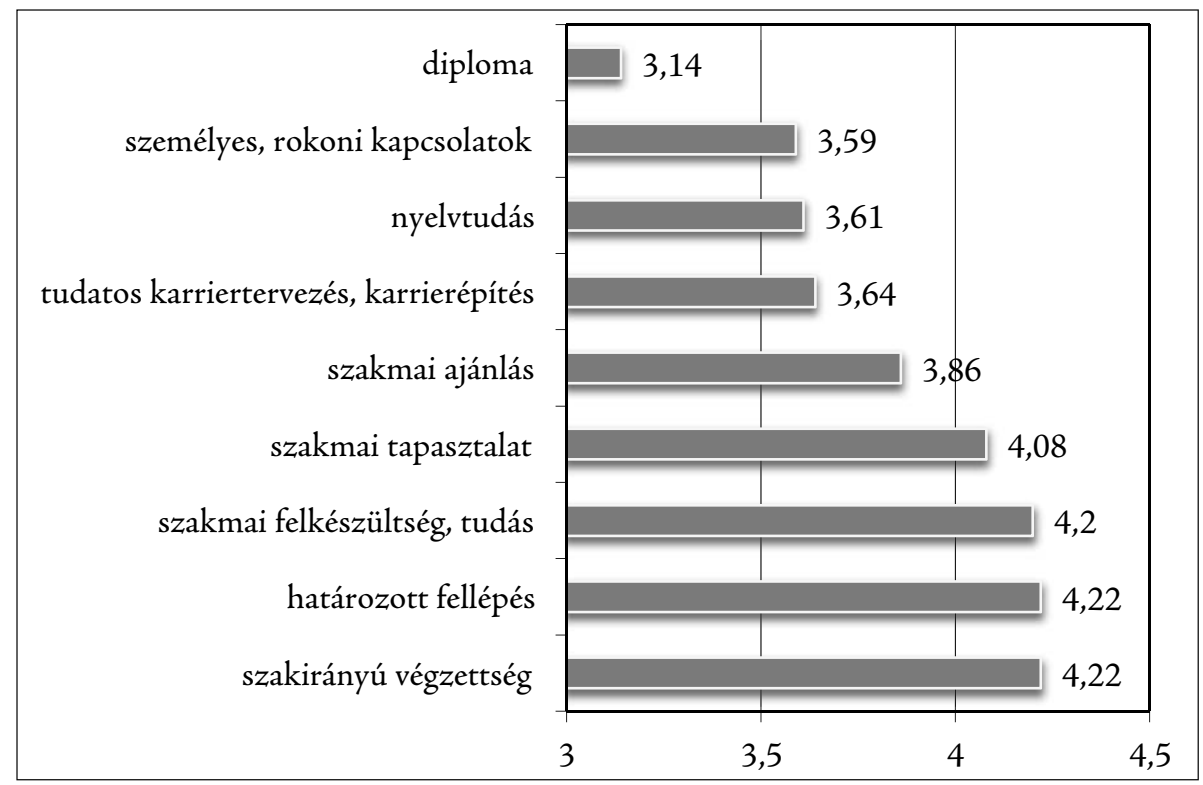

3. ábra: Véleménye szerint milyen tényezök játszanak szerepet abban, hogy az Ön szakterületén (ahol jelenleg dolgozik vagy tanul) valaki megfelelö álláshoz, munkához jusson? (1 nem játszik szerepet -5 nagyon nagy szerepet játszik. 2013, $N=1438$, fiatal felnőtt) 
bír-e valaki, vagy sem, mert ez a fizetést feltehetően nem befolyásolja. 3\% vallja azt, hogy kevesebbet keres az, aki diplomás, és $2 \%$ szerint sokkal kevesebbet keres, és inkább negatív a véleményük a felsőoktatás teljesítményéről.

A továbbtanulást tervezőktől megkérdeztük, mennyire tartják valószínünek, hogy diplomaszerzés után egy-két éven belül saját szakterületükön, a saját maguk által megfelelőnek tartott munkahelyen el fognak tudni helyezkedni. A válaszadók optimistának mondhatók a saját elhelyezkedési esélyeik megítélése szempontjából. A válaszadók 16\%-a állította, hogy diplomaszerzés után egy-két éven belül a saját maga által megfelelőnek gondolt munkahelyen biztosan el tud helyezkedni, további 76\%-uk tartotta ezt valószínünek. A válaszadók $6 \%$-a állította, hogy valószínüleg, és $2 \%$-a, hogy biztosan nem fog tudni ilyen munkahelyen elhelyezkedni.

A diploma tehát elsősorban az anyagi boldogulást szolgálja, a társadalmi presztízs értéke valamivel kevésbé fontos, az egyéni életben, identifikációban pedig különösebben nem játszik szerepet - ezt az általános képet az árnyalja, hogy negatív tónusai elsősorban a felsőoktatástól távol állók nagy arányából származnak, mert az ő számukra a felsőfokú tanulmányok elérése, hasznának realizálása fel sem merülő tényező. Bár ezek az adatok ellentmondásosnak tűnnek, ez inkább segít rekonstruálni a diploma valódi helyét az értékrendben. Láthatóan ugyanis a képzettség, a szakmai tudás egyöntetűen meghatározó a karrierépítésben a fiatal felnőttek tapasztalatai szerint, tehát az ismeretszerzés fontosságát illetően nincs kétség. Az a társadalmi tény, miszerint a diploma ennek a másfél milliós rétegnek pusztán egyharmada számára elérhető, nagy mértékben befolyásolja az általános képet. A további kétharmad számára a diploma még az álmokban sem szerepel, így az élettervezésben nem is játszhat komoly szerepet.

A lakossági minta negatívabb véleményén belül világos különbséget mutat a felsőoktatási érintettségben való különbség: a vélekedések függnek attól, hogy a válaszadónak van-e olyan gyermekük, aki jelenleg felsőfokon végzi tanulmányait. Akiknek van felsőoktatásba járó gyermeke, azok általánosan a pozitív töltetü állításokkal értenek egyet inkább, fontosabbnak és értékesebbnek tartják a diplomát. Ugyanakkor úgy vélik, hogy magas a munkanélküliség a diplomások körében, így véleményük nem idealizálja a felsőoktatás helyzetét és a diploma értékét. Azok a válaszadók, akiknek gyermeke nem jár felsőoktatásba, inkább vélik úgy, hogy az oda való bejutás függ az anyagi helyzettől, és felsőfokú végzettséggel rendelkezőkre nincs nagyobb számban szükség, a diplomások pedig lenézik az alacsonyabb képzettséggel rendelkezőket. Azok, akiknek egyetemre vagy főiskolára jár a gyermeke, inkább tartják a diplomát olyan szempontból is lényegesnek, hogy azzal könnyebben el lehet helyezkedni, és hozzájárulhat a vezetői pozícióhoz, a magasabb fizetéshez, igénylik az állami ráfordításokat, és megértőbbek a diáktüntetésekkel. A diplomáért tanuló gyermekek híján levő családok sokallják a felsőoktatásban tanulók számát és a költségvetési ráfordításokat, valamint szociális korlátokat éreznek a bejutással szemben. Vagyis a két csoport között különbség van a diploma értékét és lehetőségeit, fontosságát illetően. Ugyanakkor a hallgatókat nevelő szülők a diplomás munkanélküliség kapcsán nem redukálták kognitív disszonanciájukat, és a gyermekteleneknél is erőteljesebben egyetértenek azzal, hogy magas a munkanélküliségi ráta a diplomás végzettségüek között.

A felsőoktatás iránti bizalom egyszerre fejeződik ki az általános presztízsben és az anyagi megbecsültségről való véleményben. Itt célszerü szakterületenként vizsgálni a válaszokat, hiszen igen jelentősek az eltérések. 


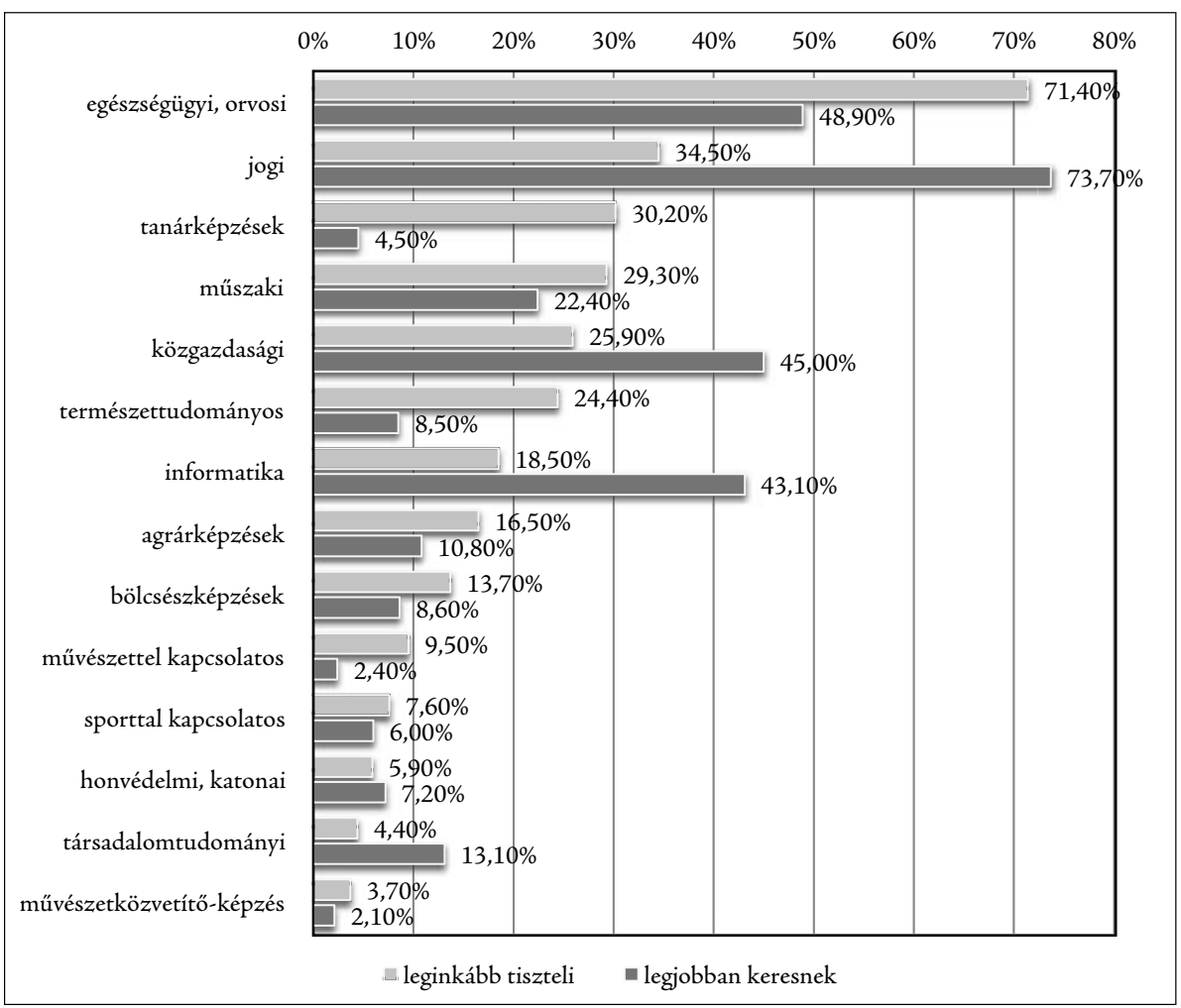

4. ábra: Ön milyen szakterületen szerzett diplomával rendelkező embereket tisztel a leginkább? Mivel lehet a legtöbbet keresni? (három szakterületet választhattak, fontossági sorendben; $N=1500$, lakossági)

Látható, hogy a kétféle reputáció a legtöbb esetben nem konzisztens. Még a leginkább magasra értékelt területek esetében is nagy az eltérés, bár összességében az egészségügyi és jogi pálya mind az anyagi boldogulás, mind a társadalmi presztízs esetében legelöl van - ellentétes irányú belső ellentmondásokkal az anyagi és társadalmi megbecsültség között. Három területen látható erőteljes értékzavar: a tanári hivatásnak lényegesen nagyobb a presztízse annál, mint amennyi a válaszadók szerint ennek a diplomának a kereseti potenciálja. Az informatikai és közgazdasági diplomák esetében fordított a helyzet, ami a közgondolkodás igen lassú elmozdulását jelzi, hiszen ezen területek a hagyományos szakmáknál fiatalabbak, és hiába a mindennapi életben való jelenlétük, nem vívtak ki komoly tekintélyt. Vannak olyan „pária” szakterületek, amelyeknek a presztízse is alacsony, és a válaszadók szerint keresni sem lehet velük (2. táblázat).

Ezt a foglalkozási presztízst visszaigazolja a KSH 2016-os mikrocenzusának eredménye (KSH 2018) is. Ebben a megjelölt 173 szakma közül a legmagasabb presztízsüek között az első ötben három orvosi (kórházigazgató, sebész, gyermekorvos) mellett az egyetemi rektor és az egyetemi tanár található. A legtöbb tudást az egyetemi rektornak tulajdonítják. Az egyetemi képzéshez közvetlenül kapcsolódó szakmák között a matematikus, biológus, pszichológus, tanárok és mérnökök az első negyedben találhatóak. 
2. táblázat: Kereseti lehetőség és tisztelet közötti különbség

\begin{tabular}{lcc}
\hline & Lakossági $(N=1499)$ & $\begin{array}{c}\text { Továbbtanulni szándékozó } \\
\text { fratal felnött }(N=148)\end{array}$ \\
\hline Jogi & $-39,2$ & -24 \\
Informatika & $-24,6$ & -25 \\
Közgazdasági & $-19,1$ & -17 \\
Társadalomtudományi & $-8,7$ & -5 \\
Honvédelmi, katonai & $-1,3$ & 4 \\
Művészetközvetítő-képzés & 1,6 & 3 \\
Sporttal kapcsolatos & 1,6 & 1 \\
Bölcsészképzések & 5,1 & 13 \\
Agrárképzések & 5,7 & -2 \\
Műszaki & 6,9 & -1 \\
Múvészettel kapcsolatos & 7,1 & 8 \\
Természettudományos & 15,9 & 11 \\
Egészségügyi, orvosi & 22,5 & 10 \\
Tanárképzések & 25,7 & 24 \\
\hline
\end{tabular}

A továbbtanulni szándékozó fiatal felnőttek körében különösen releváns, hogy a továbbtanulási szándék mennyiben találkozik a presztízzsel. A két tényező elválása mindkét csoportnál (lakosság és továbbtanulói kör) azonos tendenciájú, a mérték azonban különbözik. Míg az informatikai és közgazdasági területeken hasonló eltéréssel látja nagyobbnak a lakosság és a továbbtanulói kör a kereseti lehetőségeket, mint a szakmákat övező tiszteletet, addig a jogi pálya presztízse magasabb, kereseti lehetőségeinek nagysága alacsonyabb a fiataloknál. Az orvosi pályánál fordított az anomália, a különbség azonban itt is jóval kisebb - ennek oka nem a kereseti lehetőségek pozitívabb képe, hanem a tisztelet jelentősen (több mint negyedével!) kisebb mértéke a fiataloknál.

Összegezve tehát, a felsőoktatás iránti bizalom a társadalomban meglehetősen erős, azonban a konkrét intézményrendszeri működéssel és annak társadalmi hatásaival szemben attól függően különböznek a vélemények, hogy mennyire vannak távol az egyetemektől az egyes társadalmi csoportok.

\section{Nemzetközi kitekintés az egyetem percepciója ideológiai beállítódások szerint}

A z előzőekben a felsőoktatási részvételhez kapcsolódó szociodemográfiai változók szerint vizsgáltuk a véleményeket anélkül, hogy a világnézeti orientációkat érintettük volna. Nem véletlenül: Magyarországon nem áll rendelkezésre adat a politikai beállítódottság és az egyetemi oktatásról való vélekedések között, de egy külföldi példa tanulságos lehet a felsőoktatás társadalmi megítélésében az ideológiai hatások szerepére nézvést. Hiszen példátlan eredményủ és gyorsaságú változásokat mutat a Pew Reseach Center közelmúlt- 


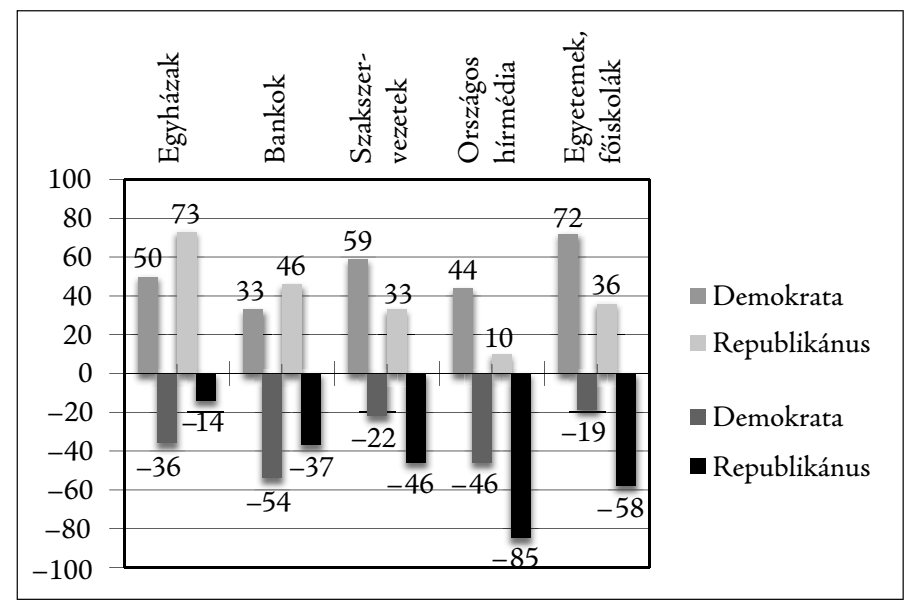

5. ábra: Pártszimpátia és a társadalmi intézmények megítélése az USA-ban

(Forrás: Pew Research Center 2017)

béli kutatása ${ }^{2}$ arról, miképpen alakult az amerikai egyetemek társadalmi percepciója az elmúlt években. Egy rendszeresen, országos mintán felvett kérdőívük eredményei azt mutatják, hogy a lakosság többsége (55\%) pozitívnak ítéli az egyetemek hatását a társadalmi életre, azonban a politikai-ideológiai táborok szerinti megoszlásban rendkívül nagy különbségeket találni. A republikánusok ugyanis sokkal kevésbé bíznak az egyetemekben, csak feleannyiuknak van pozitív véleményük, mint a demokratáknak, és háromszor anynyian ítélik negatívnak ezt a hatást!

Bár az adatsorok többi részét is tekintve (az egyházak, bankok, szakszervezetek, média) szinte tankönyvszerüen jelenik meg a konzervatívokról alkotott klisésorozat, az egyetemi világ társadalmi elfogadottsága olyan mértékben változott meg, hogy az külön magyarázatot igényel. Az amerikai egyetemek baloldali ideológiai (Klein 2006) irányultsága (legalábbis a társadalomtudományok területén) sok évtizedes jelenség, az oktatói kar ideológiai összetétele is masszívan (és nemritkán nyomasztóan) baloldalivá vált a nyolcvanas-kilencvenes évekre, bár ebben némi elmozdulás tapasztalható az ezredforduló óta (Gross-Simon 2014). (Az angol egyetemeken is hasonló folyamat - Carl 2016 - ment végbe a tudósok között: a kilencvenes évektől túlnyomóvá vált a Munkáspárt és a liberálisok híveinek száma ebben a körben.)

Az elmúlt évek egyetemi mozgásai össztársadalmi ellenérzéseket okoztak a jobboldalon. Ez nyilván nemcsak hogy nem független az általános elitkritikától, hanem éppenhogy annak egyik legfontosabb motívuma. Az amerikai jobboldal elképedve nézte, miképpen tombolnak a más véleményeket durván kiátkozó, kizáró baloldali ideológiai komisszárok a hallgatók és oktatók között. Az angolszász egyetemeken a baloldal által definiált identitáspolitikák megsértése vagy megkérdőjelezése azonnali hajtóvadászatokat vont maga után, s mindez a meghívott, konzervatív előadók elleni egyetemi lázadásokba (Maitra 2017), a vélemények sokszínűségét tagadó, agresszív egyetemi fellépésekbe torkollott, mint például a jobboldali Milo Yiannopoulos és Ann Coulter előadásának megakadá-

Pew Research Centre: Sharp Partisan Divisions in Views of National Institutions. 2017. július 10. [Letöltve: 2018.11 .30 .] 


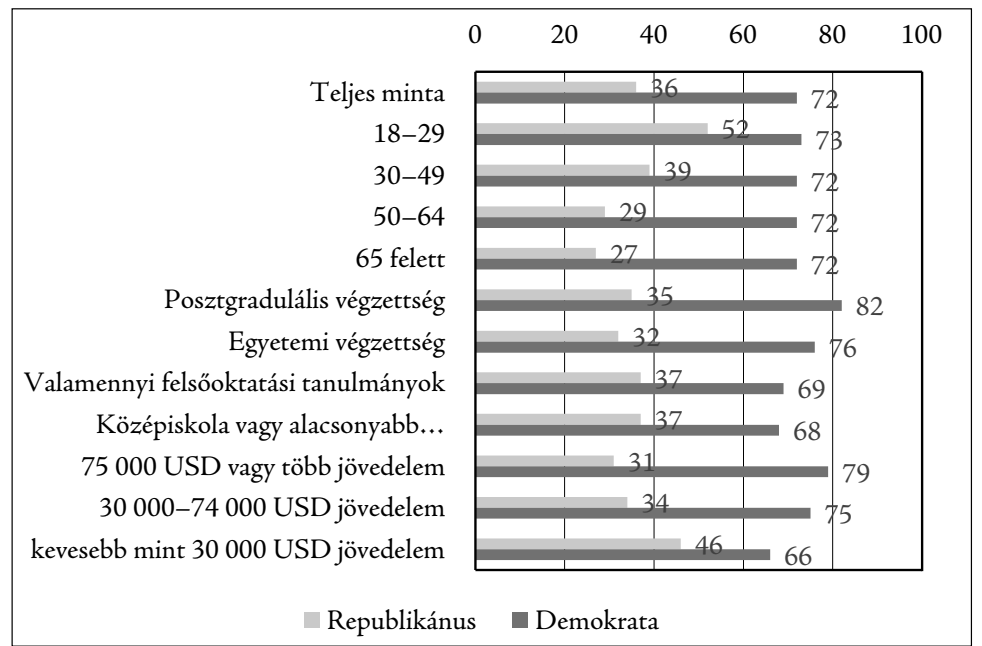

6. ábra: Pártszimpátia és a felsőoktatás megitélése az USA-ban

(Forrás: Pew Research Center 2017)

lyozása a Berkeley-n, vagy Angliában a Germaine Greer feminista ikon előadása elleni tiltakozás a Cardiffi Egyetemen.

Jól megfigyelhető, hogy az egyetemek iránti bizalom megroppanása éppen 2015-re tehető, amikor ezek az országos nyilvánosság elé kerültek. A Pew kutatása azt is mutatja, hogy a válaszadók szociodemográfiai megoszlása egyértelmű: a szegényebb, idősebb és kevésbé iskolázott rétegek republikánusai vannak jobb véleménnyel az egyetemekröl, mint a jobboldali átlag, illetve a fiatalabbak pozitív véleménye közelíti meg leginkább a demokraták általánosn igen magas ilyen arányát.

Mindez természetesen az amerikai politikai és társadalmi életre is komoly hatással van, de minket az egyetemi rendszer pozíciója érdekel itt. Az amúgy is felerősödött antiintellektualizmus közegében az egyetemek tekintélyének hanyatlása közvetlenül érintheti a finanszírozásukat, az autonómiájuk iránti igény legitimitásának megkérdőjelezését, ami súlyos következményekkel járhat sokfelé, hiszen a világ legerősebb egyetemi rendszerének fejleményei óhatatlanul szélesebb kihatásúak.

Adatok híján a magyarországi politikai megosztottság rávetülése az egyetem hazai percepciójára nem mérhető egzaktan, empirikus felmérésünkből azonban annyi következtetés levonható, hogy az általános bizalom kiemelkedő mértéke csak úgy lehetséges, ha az ideológiai polarizációkon átível a tudományos intézmények elfogadottsága. Ugyanakkor a diáktüntetésekről, a felsőoktatás általános státuszáról való nézetek megosztottsága valószínüleg annak is köszönhető, hogy ezeket a témákat a politikai közbeszéd is tárgyalta, így a véleményformálást a politikai hovatartozás befolyásolta. Ezt még inkább lehetővé teszi, hogy a felsőoktatásról a korábban alacsony hallgatói létszám miatt még mindig viszonylag keveseknek van közvetlen tapasztalatuk és egészen a 2010-es évekig nyilvánosságban is alig vált az egyetem érdemben tárgyalt témává. Így azután a felsőoktatást illető állítások konfúzan jelennek meg a válaszolóknál, hiszen az ismeretek igen hiányosak. 


\section{„Lábbal szavazni”: a felsőoktatás iránti bizalom a továbbtanulási adatok tükrében}

Az előzőekben a véleményeket tártuk fel. Ha azonban a konkrét adatokat tekintjük, akkor a felsőoktatás iránti bizalom változatlan: a továbbtanulni igyekvők korosztályi aránya az elmúlt tíz évben összességében nem csökkent, az általános demográfiai tendenciák érvényesülnek ebben. Az érettségizők között is változatlan a továbbtanulás igénye (vagyis a hallgatói létszám korlátozottsága nem a középiskola szintjén áll be.)

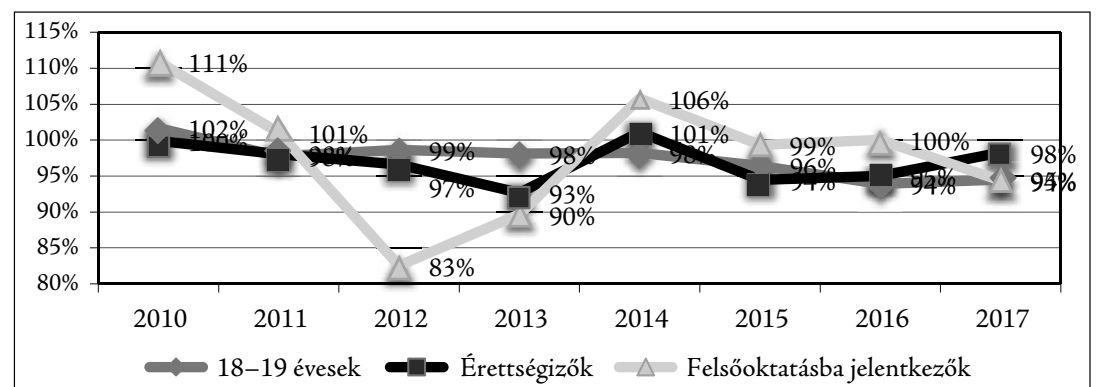

7 ábra: Érettségizők, felvételizők és korosztályi létszám az előző év százalékában 2010-2017 (Forrás: Oktatási Hivatal adatai)

A szakterületi tendenciákat figyelve a bizalmi faktor a felsőoktatás-politikai célok és az egyetemek képzési kínálatának hangsúlyai tekintetében felemásan jelenik meg: míg a tíz évvel korábbi időszakhoz képest negyedével csökkent a teljes hallgatói létszám, a preferált tanárképzési és informatikai képzési területen jelentősen több hallgató van jelen (138\% és $178 \%$ ), azonban a müszaki és természettudományi területen nagyobb a csökkenés, mint az átlag.

A közbizalom ugyanakkor egy tudásintézmény szempontjából nem csupán számossági, hanem minőségi kérdés is. Ezért a továbbtanulási tendenciák elemzéséhez célszerű a

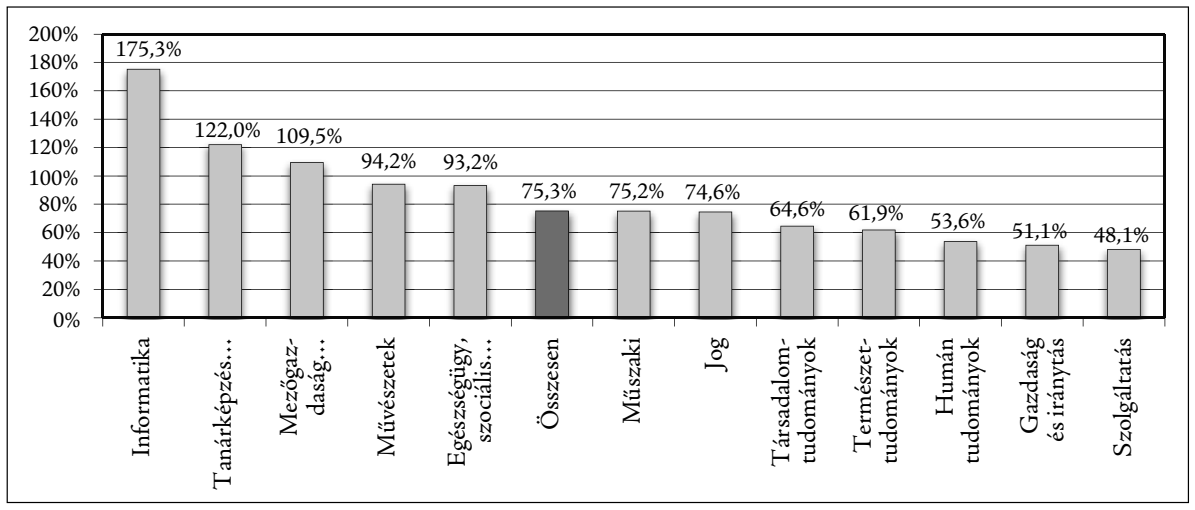

8. ábra: A hallgatói létszám változása 2009/2010 és 2017/2018 között

(Forrás: Oktatási Hivatal adatai) 
szakterület-választások kapcsán azt is megvizsgálni, hogy vajon a leginkább döntésképes helyzetü és tudatosan képzési irányt választó diákok körében miképpen alakult a bizalmukat kifejező jelentkezési döntésük?

A továbbtanulók legjobb eredményt elért 10\%-ának a szakterület-választását áttekintve azt látjuk, hogy mivel 2012-ben a gazdasági-társadalomtudományi képzési helyek állami finanszírozásának drasztikus csökkentésével lényegében összeomlott az olyan, amúgy népszerű szakok keresettsége a TOP10\% körében, mint a turizmus-ven-

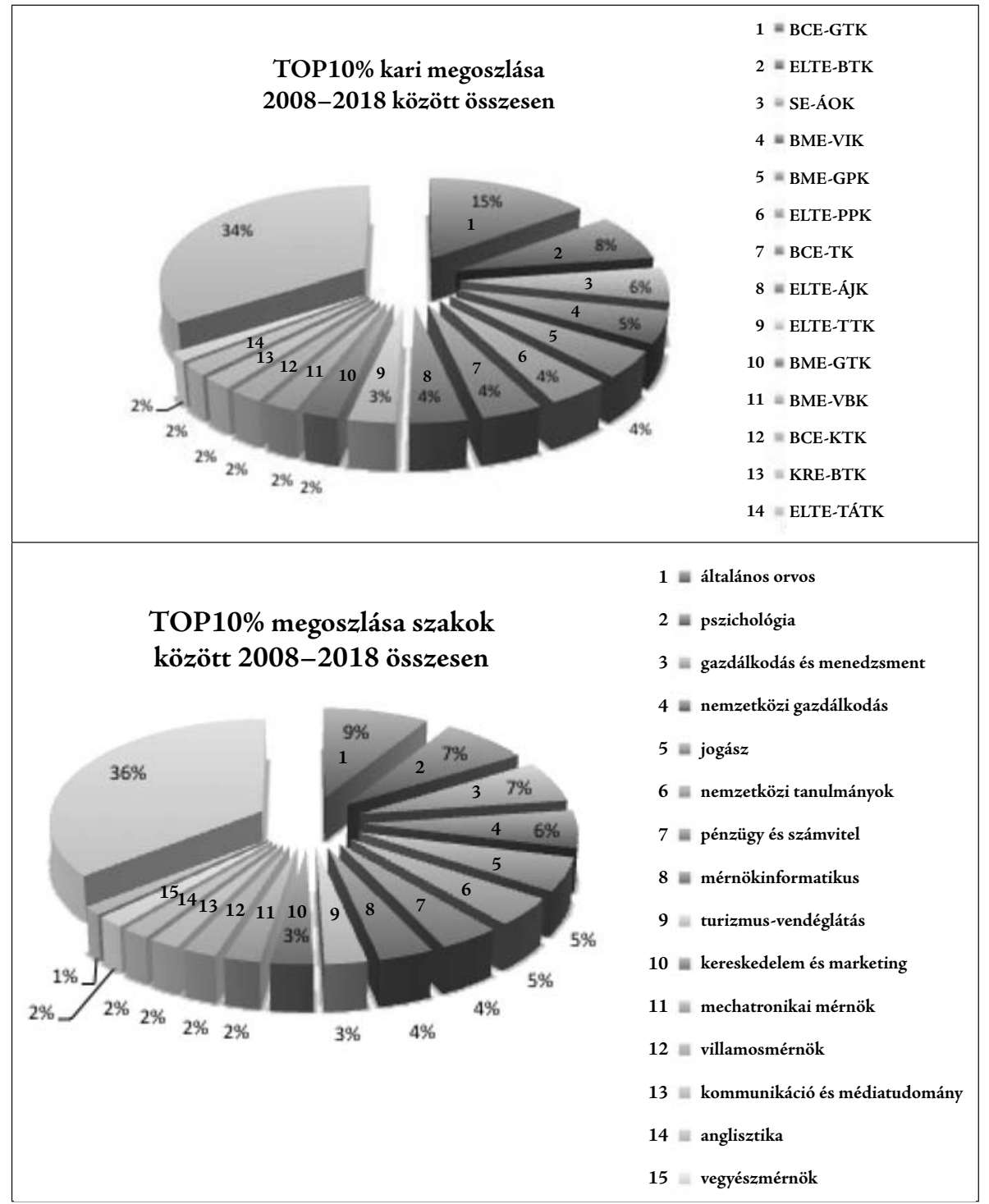

9. ábra: A legjobb tanulók által választott karok és szakok 2008-2018

(Forrás: Oktatási Hivatal adatai alapján saját számítás) 
déglátás, kereskedelem és marketing, nemzetközi tanulmányok, kommunikáció és média, az ezt követő időszak visszaépülése ellenére is ma csak az egy-két ötöde a létszám a 2008-asnak. A bölcsészeti-társadalomtudományi irányok jó része (történelem, szabad bölcsészet, politológia) esetében hasonló a változás mértéke, azonban különbözik a dinamikája: itt ugyanis folyamatos a csökkenés, fordulat nélkül. A hallgató választásainak differenciáltságát mutatja, hogy ugyanakkor a nemzetközi gazdálkodás, a jogász, gazdaságelemzés szakokon kiemelkedő bővülést látunk. A reálterületeken pedig egyértelmü a fordulat a korábbi évekhez képest: mechatronikai mérnöknek, programtervező informatikusnak, vegyészmérnöknek, matematikusnak, gépészmérnöknek, gazdaságinformatikusnak, de még általános orvosnak is lényegesen többen kezdenek el tanulni a legjobbak közül, mint a múlt évtized végén - bár néhány esetben itt az elmúlt öt évben negatív tendencia indult például a vegyészek, gépészek között. Az osztatlan tanárképzés 2013-as indulása óta fokozatosan nő az idetartozó mintegy száz szakpárra bejutó magas pontszámúak száma, aminek révén ma már elérik a 3\%-át ennek a körnek, s ez a nyolcadik legmagasabb arány.

Összességében azt látjuk, hogy mind regionálisan, mind szakterületi megoszlásban, mind intézményi oldalról folytatódott a felsőoktatási hallgatói kiválósági kapacitások koncentrálódása. A műszaki és orvosi reál szakok minőségi vonzereje megnőtt, de a tendencia néhány esetben megtorpanni látszik, viszont a természettudományos szakokat a matematika kivételével kevesebben választják a kiválóságok közül. Ha együtt tekintjük azt a félszáz ezer fiatalt, akik generációjuk legjobbjai voltak az elmúlt bő évtizedben, akkor kisebb átrendeződésekkel, de stabil érdeklődési prioritásokat látunk mind az intézmények, mind a szakok tekintetében: minden hetedik TOP10\%-os továbbtanuló a BCE GTK-t választotta, többen, mint a második ELTE BTK-t és SE ÁOK-t együtt. A szakok listáját folyamatosan az általános orvosi és pszichológiai képzés vezeti, miközben több bölcsészeti, gazdálkodási szak iránt csökken a legjobbak érdeklődése.

A magyar felsőoktatás iránti bizalmat ugyanakkor a továbbtanulók leginkább mobilis és tudásháttérrel rendelkező csoportjának, a tanulmányaikat külföldön folytatók számának és összetételének az alakulása is jellemzi. Erről nincsenek olyan egzakt adatok, mint a hazai továbbtanulásról, azonban néhány tendencia kirajzolódik a médiában és a közbeszédben nagy figyelmet keltő eseteken (például egyes élgimnáziumokból igen nagy arányú külföldre jelentkezés) túl is.

$\mathrm{A} z$ Engame Akadémia különféle nemzetközi és célországi adatbázisokat (EUROSTAT, OECD, UCAS, US Institute of International Education) használva arra a következtetésre jutott, hogy összesen mintegy 14000 magyar hallgató tanul külföldön (vélhetően ebben nincsenek benne az EARSMUS-osok, más részösztöndíjasok, diákcserések stb.). Ez a szám a magyar felsőoktatásban nappali munkarendben tanulók (cca. 220000 fő) mintegy 7 százaléka, ha pedig a teljes hallgatói csoportra (cca. 283000 fö) vetítjük, akkor $5 \%$ az arány. ${ }^{3}$

Egy nyitott, az EU-ba integrált ország esetében nem egyértelmű, hogy ez az arány a magyar felsőoktatástól való elfordulást fejezi-e ki? Ebben támpontot adhat egy összevetés a magyarok általános külföldre szóló mobilitásával: a különféle (ugyancsak nem pontos) statisztikai becslések és számítások alapján a 4600 ezer gazdaságilag aktív

http://www.engame.hu/eass/blog/kulfoldi-tovabbtanulas/943-magyar-diakok-kulfoldon-2017 [Letöltve: 2018. 11. 30.] 
korúhoz képest 400-600 ezer közöttire teszik a tartósan külföldön dolgozók számát, vagyis a teljes munkavállalói kör 10-15\%-ára. Bármekkora is a pontos adat, az látszik, hogy lényegesen magasabb a felnőttek, tehát elvileg kevésbé mobilak aránya a külföldre távozásban, mint az egyetemistáké. Nyilván sokféle interpretációja lehetséges ennek, de mindenképpen érdemes ezt a tényezőt is figyelembe venni a magyar felsőoktatás kínálatának, illetve ehhez kapcsolódva a magyar fiatalok életpálya-építési stratégiáinak értékelése kapcsán.

A nemzetközi mobilitás másik iránya is bizalmi faktort jelez. Az elmúlt tíz évben több mint megkétszereződött a külföldi hallgatók száma a magyar felsőoktatásban, a nappalis hallgatók közötti arányuk pedig megháromszorozódott. Ennek okai között a célzott kormányzati támogatási programok (például a Stipendium Hungary) biztosan komoly tényezőt jelentenek, de ezzel együtt is kifejezik az adatok a magyar egyetemek iránti bizalom egy formáját.

\section{Bizalom és a felsőoktatás-politika}

Láthattuk tehát, hogy a magyar felsőoktatás társadalmi környezetét és „felhasználóit” egyaránt alapvetően bizalom jellemzi. Ugyanakkor 2010 után a felsőoktatás-politikát leginkább éppen az egyetemek müködésével szembeni bizalmatlanság jellemezte. Ez elsősorban az intézmények gazdálkodására és az akadémiai elit vezetői képességére terjedt ki, az egyetemek társadalmi szerepével, kritikai szellemével és szakmai egyenszilárdságával kapcsolatos negatív vélemények csak a legutóbbi időkben fokozódtak egyetemellenes ideológiai kampányokká. Utóbbiak azonban (a CEU elleni fellépések, illetve az egyetemek gazdálkodóképességének megkérdőjelezése kivételével) még nem érték el az igazgatási beavatkozás szintjét, ezért itt az irányítási bizalmi helyzet modellezésére szorítkozom, bemutatva, hogy milyen formákkal volna a bizalom és felelösség elve egyszerre érvényesíthető a magyar szabályozási környezetben is ${ }^{4}$.

A fenntartó célja világos: hatékonyan gazdálkodó és társadalmi-gazdasági küldetését teljesítő egyetemet kíván, amihez ennek létrejötte esetén (átlátható mechanizmusokkal és hosszabb távra tervezhető módon) biztosítja a forrásokat. Az egyetemek a menedzselés hatékonyság és forrásbiztosítás egyensúlyában (szakmai és társadalmi felelősségük tudatában) legjobb tudásuk szerint, ésszerü menedzseléssel kutatnak és oktatnak.

Ezeknek az elveknek az érvényesülése nyilvánvalóan a leginkább kedvező környezet a felsőoktatási tevékenységekhez, beleértve a nemzetközi beágyazódás és versenyképesség javulását is. Azért is szükséges a bizalom elvének egyenrangúsága a jogi és szervezeti megoldásokkal, mert hiánya az adminisztratív-hatalmi túlbiztosítások versus kiskapukeresések, teljesítménymanipulációk körforgását eredményezi.

A bizalmi elv lehet képes a szabályozási túlbiztosítást és annak szabálykerülő reakcióit meghaladni. A kancellár-konzisztórium-autonómia koordinátarendszerben ez a bizalom konkrét szervezeti megoldásokban is megjelenne: az egyetemet vezető és képviselő rektort az egyetem választja, aminek az eredményét a fenntartó csak törvényességi szempontból vizsgálhatja, és a kancellár, illetve a konzisztórium tagjainak személyéről szintén véleményt nyilvánít. Így az egyetemi közösség sajátjának érezheti a menedzs-

\footnotetext{
Az alábbiakban a 2015. május 3-án közzétett „Bizalom-csomag a felsőoktatásért” bejegyzés tartalmát fog-
} lalom össze. (www.egyetemipolgar.hu [Letöltve: 2018. 12.05.]) 
ment egészét, az akadémiai döntéshozók együttműködési és pénzügyi felelősségének deklarálása a fenntartónak-finanszírozónak adhat elegendő biztosítékot a hatékony müködésre.

Látható ebben a megközelítésben, hogy a bizalom működése sokkal gördülékenyebb és az együttmüködést segítő megoldásokat eredményez, amivel szemben a bürokrácia növekedése és az újabb és újabb szabályozási kényszereket, vagyis belátható időn belül az ilyenkor óhatatlanul kialakuló jogi káoszt hozó centralizálás az alternatíva (Rónay 2017).

\section{Összegzés}

Láthattuk, a bizalom nem csupán egy elvont eszme, hanem konkrétan mérhető viszonyulás az egyetemek számára meghatározó társadalmi környezet részéről s egyben a leghatékonyabb intézményszerveződési elv a felsőoktatásban. Ennek az érvényességét egy angol példából is érzékelhetjük, ami a társadalmi bizalomnak sajátos megnyilvánulását tette lehetővé. $\mathrm{A} z$ angol egyetemek az elmúlt években elkezdtek kötvényeket kibocsátani.

A világ egyik legjobb egyeteme, az Oxford University követte a forrásteremtés nem szokványos útján ezzel a Cardiff University megoldását. Korábban mások között Cambridge is már megjelent egy negyvenéves lejáratú kötvénnyel, amire 3,75\% lett a kamat, de Oxford igazán nagyot dobott: 100 éves lejárattal dolgozik!

Felsőoktatás-finanszírozási oldalról nézvést arról megoszlanak a vélemények, hogy vajon ez a folyamat nem taszítja-e az egyetemi világot az eladósodás spiráljába? Az bizonyos, hogy az állami támogatásokhoz képest ez a megoldás erősíti az egyetem gazdasági függetlenségét, azonban nyilván csak akkor járható út, ha kőkemény gazdasági, gazdálkodási és egyetemstratégiai kontrollok biztosítják a célszerü felhasználást.

De egyetempolitikai szempontból vonatkoztassuk ezt a felsőoktatás társadalmi percepciójának kérdésére! Egyfelől itt a lehető legközvetlenebb visszaigazolást kapja az egyetemi teljesítmény a társadalmi-gazdasági környezettől: pénzt adnak a kötvényvásárlók az egyetem várható teljesítményére, bevételtermelő képességére. Ezt nyilván a múltbéli tapasztalatok (hagyomány, presztízs), másfelől a tudásipar rentábilitásáról kialakult kép alapozza meg. Másfelől, gondoljuk meg, micsoda bizalom kell övezzen bármilyen vállalkozást, intézményt, tevékenységet, hogy a mai világban reálisnak tartsuk 100 év múltán is a fennállását, működését?! Ez az, amit az egyházakon kívül vélhetően csak az egyetemekről vagyunk képesek elhinni...

\section{IRODALOM}

Cart, N. (2016) Lackademia. Why Do Academic Lean Left? London, Adam Smith Institute.

Gross, N. \& Simon, S. (2014) Professors and Their Politics. Baltimore, John Hopkins University Press.

KSH (2018) Mikrocenzus 2016. 13. A foglalkozások presztízse. Budapest, KSH kiadvány.

KLein, P. G. (2006) Why Intellectuals Still Support Socialism. Mises Dally Articles, 2006. november 11 . 
Maitra, S. (2017) The Berkeley Riots and the Tyranny of the Righteous Minority. Quilette, 2017. február 2.

RónAY, Z. (2017) Egyéni és testületi felelősség a felsőoktatási intézmények vezetésében. $\mathrm{PhD}$-értekezés.

A cikk a Creative Commons Attribution 4.0 International License (https://creativecommons.org/licenses/ by/4.0/) feltételei szerint publikált Open Access közlemény, melynek szellemében a cikk bármilyen médiumban szabadon felhasználható, megosztható és újraközölhető, feltéve, hogy az eredeti szerző és a közlés helye, illetve a CC License linkje és az esetlegesen végrehajtott módosítások feltüntetésre kerülnek. (SID_1) 